\title{
Application of Remote Sensing in Earth Sciences - A Review
}

\author{
Adel Shirazy \\ $\mathrm{PhD}$ \\ Shahrood University of \\ Technology \\ Shahrood, Iran
}

\author{
Aref Shirazy \\ PhD Candidate \\ AmirKabir University of \\ Technology \\ Tehran, Iran
}

\author{
Hamed Nazerian \\ $\mathrm{MSc}$ \\ University of Catania \\ Catania, Italy
}

\begin{abstract}
The application of remote sensing sciences in the field of geology is very diverse and wide. One of its most important applications in earth sciences is geological mapping. Mineral exploration using remote sensing techniques is done in different ways, one of them is the mapping alteration zones related to mineral resources. Given the importance of remote sensing and geosciences in today's industry and given that deposit-related alteration areas are one of the most important exploratory keys. in this review study the mapping methods and alteration zones detection using remote sensing techniques and other applications of remote sensing in earth sciences and its generalities are explained.
\end{abstract}

Keywords: Remote Sensing, ETM, ASTER, Alteration, Exploration, Earth Sciences.

\section{INTRODUCTION}

Mineral resources as the first link in the production chain play an undeniable role in the development, growth and prosperity of a country and form the basis of the economy and industry [1-4]. From the beginning of its creation and throughout history, human beings have used minerals according to their needs and knowledge [5, 6]. In other words, these minerals form the basis of civilization. Therefore, mineral exploration has special importance as the first step in this cycle [7, 8]. Along with the production and advancement of science, technology, and innovations such as remote sensing, GIS, and global positioning systems, traditional methods of mineral exploration have been replaced by new methods $[9,10]$.

Remote sensing is technique of collecting information about land surface features without physical contact with them. Remote sensing has great potential for identifying altered areas associated with deposit masses thus is known as a standard method in the field of mineral exploration and it can help to study geochemical explorations [11-15]. [Remote sensing data] has special capabilities compared to data collection methods due to its integrity and breadth, spectral diversity, duplication of coatings, and cheapness, which today is the first factor in the study of land surface and its constituent factors [16]. The digital nature of data has made it possible for computer systems to use this data directly [17, 18]. Quick access to remote areas and their high accuracy are the special advantages of this technology. Remote sensing techniques play an important role in locating mineral deposits and significantly reduce the costs of initial exploration and semi-detailed studies. It is very useful to use satellite imagery when making geological maps, improving the quality of maps and preparing thematic maps. Remote sensing is used in various sciences such as geology, archeology and environmental sciences. A new generation of advanced remote sensing has been used in recent decades in the mineral exploration, the exploration of oil reserves, the environmental study and agriculture [19].

The application of remote sensing in the field of geology is very wide, one of which is related to geological mapping using remote sensing. Some geological surveys using remote sensing :

$$
\begin{array}{ll}
\text { - } & \text { Identify the type of stone [20]. } \\
\text { - } & \text { Structure identification [21]. } \\
\text { - } & \text { Structural and hybrid mapping [22]. } \\
\text { - } & \text { Exploration of oil reserves [24]. } \\
\text { Exploration of mineral resources [25]. } & \text { Water resources [26]. }
\end{array}
$$

Exploration of mineral resources by remote sensing is done by the following three methods [27].

- $\quad$ Alterations mapping

- $\quad$ Structures mapping

- $\quad$ Hyperspectral mapping

In this study, has tried to collect and present methods related to the application of remote sensing in mineral resource exploration [28-30].

\section{REMOTE SENSING \& LITHOLOGY}

In this section, the properties of the igneous, sedimentary and metamorphic rocks that help us to identify them using satellite images processing and remote sensing techniques, are mentioned [31].

\subsection{IGNEOUS ROCKS}

Intrusive igneous rocks usually cover tens of square kilometers areas and have a relatively homogeneous texture. These rocks may have joints, faults, or arc-shaped dykes in their margins and be affected by joint systems throughout the area. Intrusive coarse-grained rocks are easily eroded into well-drained and thick soils, while fine-grained rocks are more resistant to erosion. Felsic intrusive stones like granites, are lighter in color, while mafic intrusions, such as gabbro, are darker in color. Mafic minerals are usually eroded by clay due to erosion and alteration, and show a milder topography than granite soils. Ultramafic units, carbonates and kimberlites have an unusual morphology and narrow rangelands [32].

One of the characteristics of intrusive igneous rocks is the presence of veins filled with mineral deposits, which are 
usually observed at the site of ring, radial faults or at their intersection. These streaks are usually characterized by their associated faults, their resistance to erosion, or their light color. Extrusive igneous rocks often have specific areas. Volcanoes, volcanic cones, and lava flows are all easily recognizable. Craters are often identified by radial or ring dykes and craters filled by lakes. Most of the volcanic rocks are granular and have very strong layers that form steep precipices. It is difficult to distinguish tuffs from erodible sedimentary rocks. They have very bright colors. Basalts are often dark and sometimes seen as flowing lavas. In some areas, basalts form dark, resistant layers that cover tens of square kilometers. Most of the volcanic soils contain red soils, which are formed as a result of rapid weathering of ferrous minerals. These features can be used to detect igneous rocks using remote sensing methods [33].

\subsection{METAMORPHIC ROCKS}

Metamorphic rocks can be identified by adhesions and scratches. Low-pressure rocks, such as schists, are usually dark in color and highly erodible along their foliage, but in some areas they may be difficult to distinguish from sedimentary rocks. Metamorphic rocks, unlike intrusive igneous rocks, are heterogeneous and therefore do not have uniform color and surface texture [34].

\subsection{SEDIMENTARY ROCKS}

Sedimentary rocks are characterized by strong and weak alternating layers with various thicknesses and colors. The appearance of different types of rocks depends on their grain size, composition and weathering environment [10].

\subsection{SANDSTONES}

The sandstones are mainly composed of quartz and feldspar and form resistant ridges. Of course, this resistance depends on the type and degree of cementation of the sandstones. Silica cements are more resistant than calcite cements and both are more resistant than clay and gypsum cements. High porosity sandstones usually have little surface runoff and canals flow at a distance from each other. High permeability promotes the growth of plants with deep roots in sandstones. Due to the high fragility and strength of sandstones, joint systems are widely used [35].

\subsection{SHALES}

Shales are either clay particles or clay-sized quartz. Due to their fineness, they are highly erodible and form shallow valleys in wet areas. Due to the high surface flow, the waterways flow at a very short distance from each other. Because Chilean units are more likely to be malleable, the joints in them do not develop well. Shales are prone to landslides and generally have a mild topography [36].

\subsection{CARBONATITES}

Carbonatites are crystalline and therefore resistant to physical weathering. In arid areas, they form bumps and break easily. In humid areas they are resistant but have a circular morphology. Carbonates are usually light in color, although they may darken due to weathering. One of the important features of carbonates is the presence of karsts or wells in them. They create areas of spots [37].

In such areas, the pattern of canals is erratic because the canals suddenly collapse into the wells or all the precipitation penetrates between the joints. In arid areas, carbonates produce little soil, have steep valleys, and most plants grow in wells where moisture accumulates. In wet areas, plants are more concentrated. Residual clays with carbonates form red soils in wetlands. There is no clear way to distinguish between limestone and dolomites except by high-resolution imaging spectroscopy in areas where vegetation is scarce or nonexistent. Dolomites are often highly fractured and erode more easily than limestone. Therefore, dolomites may be black in a certain area if lime is gray [38].

\subsection{EVAPORATION}

Evaporates, such as halite and gypsum or anhydrite, are present only in arid areas on the surface. Because they are soluble in water. They are recognizable because they are very bright and white. They are found in the form of domes, salt lakes and rarely in sand dunes. Subsurface evaporations are the evaporative layers below the earth's surface. They are usually characterized by the morphology which is created on the surface. Salts usually form dome-shaped diapers. The moving nuclei of thrust folds, like salt domes in the folded Zagros belt, sometimes reach the surface in the form of domes [39].

\subsection{SPECTRAL LITHOLOGY}

Satellite images can be effective in identifying different stratigraphic units by determining the spectral characteristics of rocks and minerals. For example, Hunt and Salisbury provided near-infrared and infrared wavelength reflection curves for sandstone, shale, and limestone. According to these curves, units with similar stratigraphy show similar reflection curves, based on which many geologists have mapped rock units in different areas using their respective reflection curves. In Fig1 Spectral diagrams of minerals in sedimentary rocks are presented, which comparison between these curves with the main curves help us in the exploration and detection of sedimentary rocks [40].

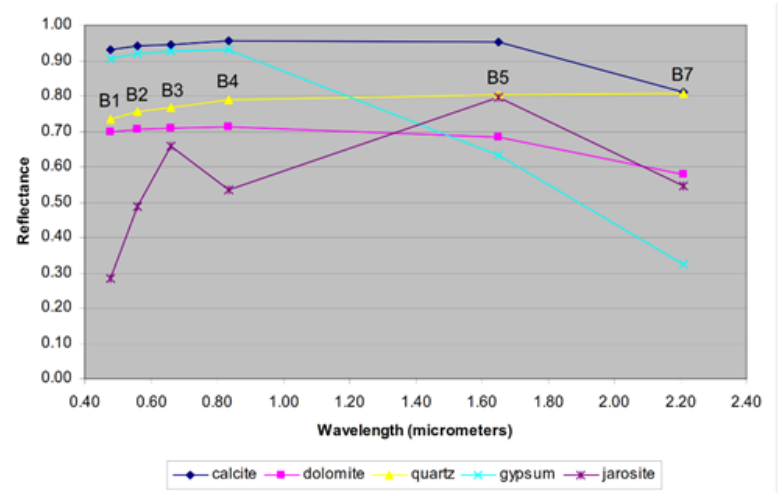

Figure 1: Reflection curves for some minerals found in sedimentary rocks

\section{REMOTE SENSING EXPLORATION OF MINERALS}

AND

To date, two different methods have been used in studies related to mineral exploration using remote sensing techniques [8].

1- Pattern mapping of fractures and faults at the regional and local scale to detect their control over critical reserves. For example, a comparison of the pattern of ridges in Nevada with areas with mineral reserves showed that mineral deposits occur along these ridges and their focus is at the intersection of these ridges. According to the studies of Nicholas (1974) and based on the pattern of local fractures in Landsat images in Colorado, it was found that more mineral deposits are formed in areas with high fracture density. 
2- Detection of rocks that have undergone hydrothermal alteration and may be associated with mineral deposits. In the meantime, Landsat image TM has been most used in this field, especially for the detection of alteration minerals such as iron oxides, clays and alunites.

The reflectance spectra of minerals are well known. Many studies have been done to determine the reflection spectrum of rocks. The reflectance spectra of minerals are measured by spectroscopic instruments of varying resolution and stored in spectral libraries that are stressed in digital formats. When a beam of light hits the surface, some of it is absorbed and some is scattered or reflected. The reflected rays of different objects are measured in the laboratory or in the desert. Field spectroscopes reflect the reflection of objects by dividing the radiant energy reflected from the intended target by the radiant energy reflected from a reference (radiant material)100\%). Barium sulfate is usually used for reference in field spectrometers. Sunlight is usually sufficient for the light source [41].

\subsection{SPECTRAL CHARACTERISTICS OF CLAY MINERALS}

Clay minerals generally include smectite, kaolinite and illite. Smectite is a group of clay minerals that is characterized by three layers including two layers of silicon and oxygen tetrahedron and one layer of aluminum and hydroxyl octahedron, the most important member of which is montmorillonite. In these layers, water molecules are absorbed between the layers. Montomorillonite approaches a strong absorption spectrum 1.4, 1.9, 2.2 micrometers. The spectra of illite, montmorillonite and muscovite have almost the same absorption bands. Like montmorillonite, illite shows an absorption band of 1.4 and 1.9, as well as 2.2, 2.3 and 2.4 micrometers [42].

Kaolinite is one of the clays that consists of two layers of silica in the form of tetrahedron and aluminum in the form of octahedron. Absorption properties of the whole kaolinite range are 2.2 micrometers and 1.4 micrometers. Figure 2 shows the reflection spectra of the three groups of illite, kaolinite and montmorillonite in the short infrared spectral range [43]
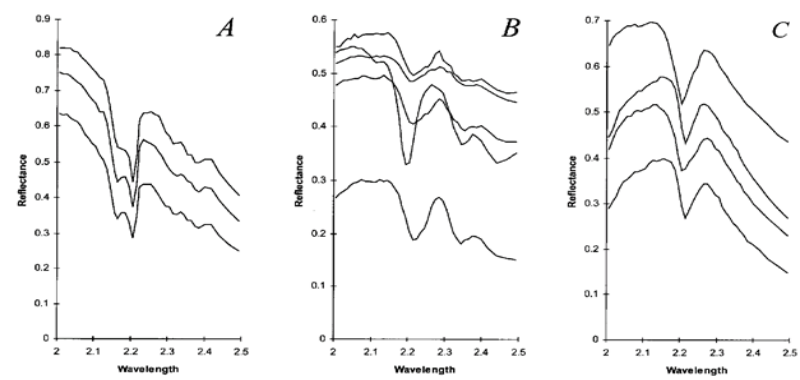

Figure 2: Spectral range reflection spectrum SWIR Three groups (A illite, B kaolinite and C montmorillonite)

\subsection{SPECTRAL CHARACTERISTICS OF IRON OXIDES}

The spectrum of iron oxides has the highest reflection in the visible red band, $0.7 \mu \mathrm{m}$ and the lowest reflectance at 0.9 and $0.4 \mu \mathrm{m}$. Reflective spectra of iron oxides, mostly hematite, goethite, and limonite, were studied by Rowan to identify the alteration zone associated with the Goldfield mineralization in Nevada (Figure 3). The reflection spectra of some iron oxides from the data TM in the Goldfield mine is shown in the figure 3 [44].

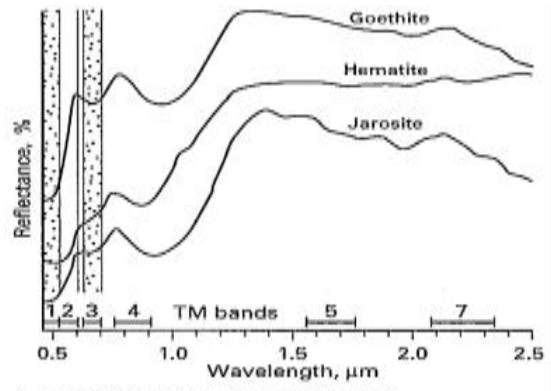

A. Laboratory reflectance spectra.
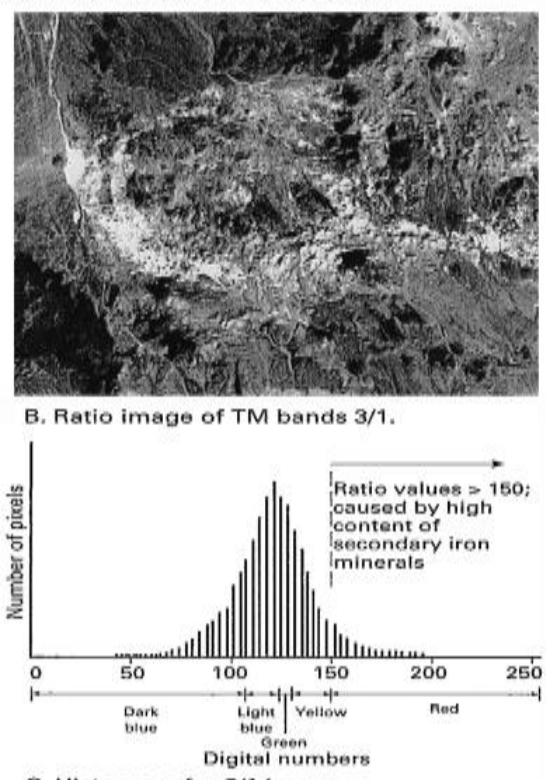

C. Histogram for $3 / 1$ image.

Figure 3: Curve of reflection spectra of iron oxides and bandwidth of 1/3 of TM data in Goldfield mine

\section{APPLICATION OF LANDSAT IMAGES}

The Landsat remote sensing satellite was designed and built by the American Ground Observation Satellite Company. Landsat is the name of a series of satellites designed to collect information from terrestrial sources in a regular and systematic framework. [Satellite] information can be used to determine land use, geological and mineralogy exploration, forestry and agriculture management, and cartography [45].

\subsection{DETECTION OF CLAY MINERALS BY DATA TM}

Reflectance spectra of alunite and three important clay minerals are shown in figure 4 . These minerals show the least reflection and the most absorption in band 7TM but they have the most reflection in the band 5 TM. Images from comparison can emphasize these spectral differences. Band ratios 5/7 in pictures ETM+ Or TM is effective in detecting clay minerals. Table 1 shows how to distinguish 5/7 ratio of altered stones from unaltered stones. The reflection of unaltered rocks in band 7 is similar to band 5 but both rocks have the same reflection in band 5. Therefore, the ratio of 5/7 non-altered rocks is equal to one, while in altered rocks it is 1.45 because the altered rocks have less reflection in band 7 . The numbers in the table are typical and can be different for other examples. Figure 4 shows a 5/7 aspect ratio image of the 
Goldfield mine that shows a higher aspect ratio value with a lighter tone, as well as a 5/7 aspect ratio image histogram that shows the aspect ratio of the altered rocks [46].

Table 1: Ratio values of $\mathbf{5 / 7}$ for altered and unmodified rocks in Goldfield mine

\begin{tabular}{|c|c|c|c|c|}
\hline $\begin{array}{c}\text { Type of } \\
\text { stone }\end{array}$ & $\begin{array}{c}\text { Band } \\
\text { reflection 5 }\end{array}$ & $\begin{array}{c}\text { Band } \\
\text { reflection 7 }\end{array}$ & Ratio 5/7 & $\begin{array}{c}\text { Digital } \\
\text { number } \\
\text { ratio 5/7 }\end{array}$ \\
\hline $\begin{array}{c}\text { Unaltered } \\
\text { stones }\end{array}$ & 160 & 160 & 1.00 & 100 \\
\hline $\begin{array}{c}\text { Altered } \\
\text { stones }\end{array}$ & 160 & 110 & 1.45 & 145 \\
\hline
\end{tabular}

\subsection{DETECTION OF FERROUS MINERALS BY DATA TM}

Iron ores are the second class of markers of altered rocks in Figs 3. The reflection spectra of these minerals are shown. They are in the blue band TM The least reflection and in the red band TM. They have the most refinement. So ratio of 3/1 in pictures TM is effective. In the second picture of figure 4 high digital values are displayed in clear case only [47, 48].

\section{USING HYPERSPECTRAL IMAGES TO EXPLORE MINERALS}

Hyperspectral scanners are special type of multispectral scanners that have tens of bands with a width of approx 0.1 $\mu \mathrm{m}$. These images can provide more accurate and detailed data on minerals. There are two ways to produce images that specify the frequency and distribution of individual minerals by these images [49]:

1. As mentioned, many alteration minerals, especially clays, reflect a similar spectrum. Absorption spectra of clays with slight differences is 2.2 micrometers. These slight differences help to identify the range of different clay minerals. Image processing programs can range from one pixel AVIRIS compare the reference for known minerals in comparison with the laboratory range. This process is a kind of supervised classification and can only be effective for soil segregation in which there is only one single mineral.

2. Resolution AVIRIS is 20 by 20 meters. In areas with complex geology, a pixel with an area of 400 square meters contains different types of minerals. This pixel is a mixed pixel which is called a spectrum because it is a mixture of the spectra of different minerals in a cell that occupy 20 by 20 meters. These single minerals are called spectral samples. Distinctive digital programs are used to extract the spectrum of each individual mineral for each mixed pixel. For each sample, a sample frequency image is generated that shows its relative frequency.

TM images shows a broad pattern of hydrothermal alteration, while AVIRIS images show the distribution of individual alteration minerals.

\section{USE OF ASTER IMAGES IN MINERAL EXPLORATION}

Over the past decade, new remote sensing satellites, hyperspectral, and multispectral satellites have been launched into space, providing data with higher spectral resolution that can be useful for mineral exploration. In addition, laboratory spectral data for rocks and minerals such as spectral libraries USGS and JPL are considered as a complement to spectral measurements and allow geologists to identify individual rock units. Recent advances in remote sensing have made the use of this technology an important tool in mineral exploration, especially for areas with difficult access or areas without topographic and geological maps [50].

As mentioned, over the years a wide range of TM images with four bands VNIR and two bands SWIR has been used to detect iron oxides in bands VNIR and clay minerals in SWIR. However, ASTER images are similar to TM images in terms of spatial resolution, but existence of 6 bands SWIR increased ASTER ability relative to TM images. Another advantage of ASTER images is the existence of 5 thermal bands that allow the detection of quartz, potassium-containing feldspar, minerals containing $\mathrm{CO} 3$ and gives igneous rocks to geologists using spectral radiation curves and band ratios.

Each of the image bands of ASTER like TM Indicates some minerals. Absorption properties of bands 1 and 3 of ASTER mainly identifies iron oxides. While the absorption spectra of the bands 5 and 6 identifies aluminum hydroxides in clay minerals, alunite and muscovite. Band 7 also identifies iron hydroxides such as jurassites and ferrous muscovites, and band 8 is used to identify minerals containing magnesium hydroxide such as epidote, chlorite, and carbonate. Laboratory reflection data curves of kaolinite, alunite, muscovite and montmorillonite minerals corresponding to channels SWIR and VNIR that are extracted from the spectral library of ASTER Are shown in Figure 4 [51].

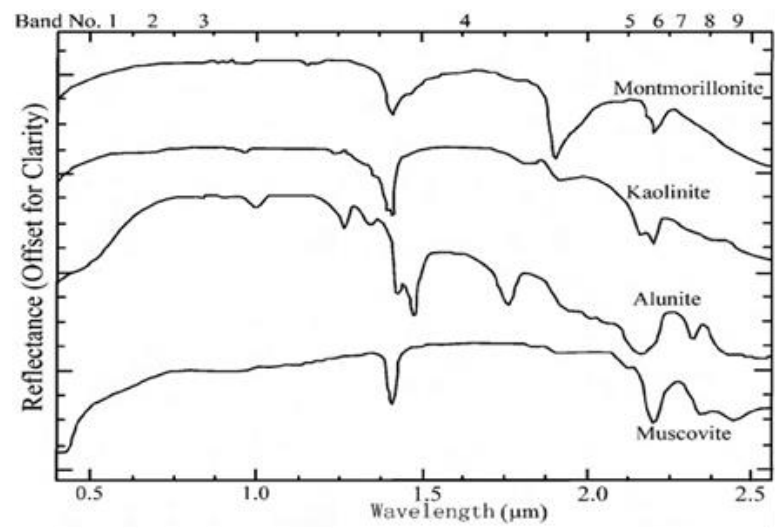

Figure 4: Laboratory reflection data curve of kaolinite, alunite, muscovite and montmorillonite minerals from spectral library ASTER

Dittomaso and Robinstein (2007) studied spectral reflection of alteration minerals in porphyry mine Infiernillo in Argentina by pictures of ASTER. In Figure 5 The first curves correspond to the combination of muscovite and illite. The second curve is consistent with the combination of iron 
oxides and jurassite, the third curve shows a combination of illite and kaolinite, which shows small absorption properties at $2.16 \mu \mathrm{m}$. Curve four shows a combination of illite and jurassite with absorption properties at 0.8 and $2.26 \mu \mathrm{m}$. Curve 5 is consistent with chlorite. They use these spectral sections as a reference for mapping alteration minerals using images [52].

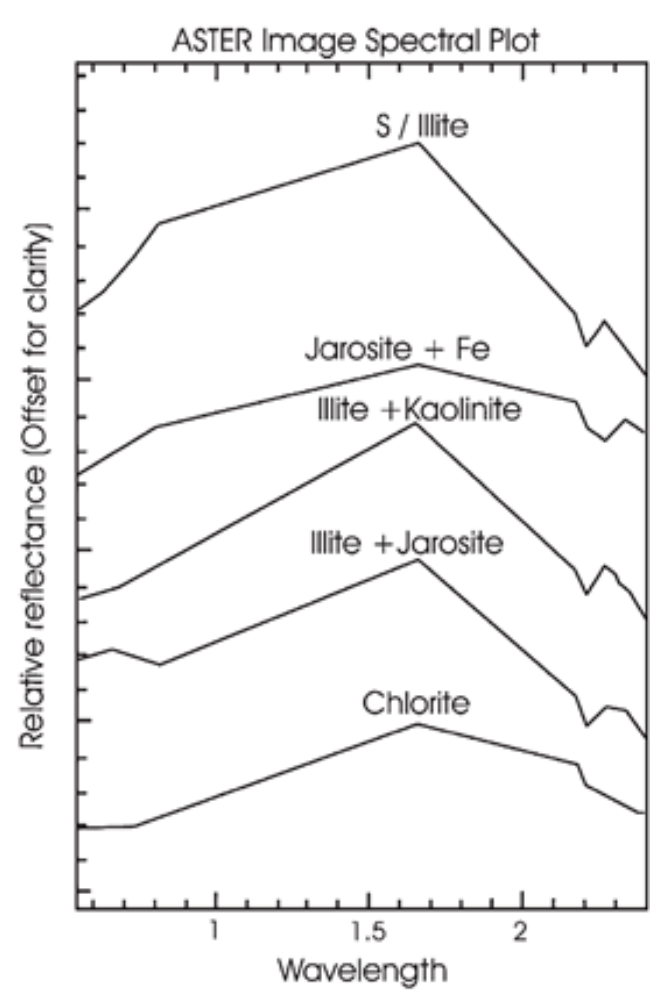

Figure 5: Spectral reflection of alteration minerals in porphyry mine Infiernillo in Argentina

Ravan and March (2003) presented spectral characteristics of important rock-forming minerals in the pass mountain in California, the results of calibration and re-sampling of locally measured reflective of 9 bands SWIR and VNIR. Comparison of laboratory reflection spectra with high resolution of selected minerals with reflectance spectra of ASTER images from resampling shows that ASTER image ,despite [50] their low resolution, are recognizable and interpretable. The effect of factors such as the presence of mineral-mineral mixtures, plant-mineral mixtures, variable grain size and atmospheric effects reduces the quality of the reflected spectra in the images. The differences in the reflectance spectrum between carbonate minerals (calcite and dolomite) and muscovite minerals (aluminum-bearing and iron-bearing muscovite) are significant in both ASTER and laboratory spectra. Figure 6 shows the steps of calibrating |ASTER images for mapping. Ninomia (2003) presented a mineralogical index using 6 SWIR channels that are used to detect alteration minerals [53].

$$
\begin{aligned}
& \mathrm{OHI}=(\text { band } 7 / \text { band6 }) \times(\text { band } 4 / \text { band6 }) \\
& \mathrm{KLI}=(\text { band } 4 / \text { band5 }) \times(\text { band } 8 / \text { band6 }) \\
& \mathrm{ALI}=(\text { band } 7 / \text { band5 }) \times(\text { band } 7 / \text { band } 8) \\
& \mathrm{CLI}=(\text { band6 } / \text { band } 8) \times(\text { band } 9 / \text { band })
\end{aligned}
$$

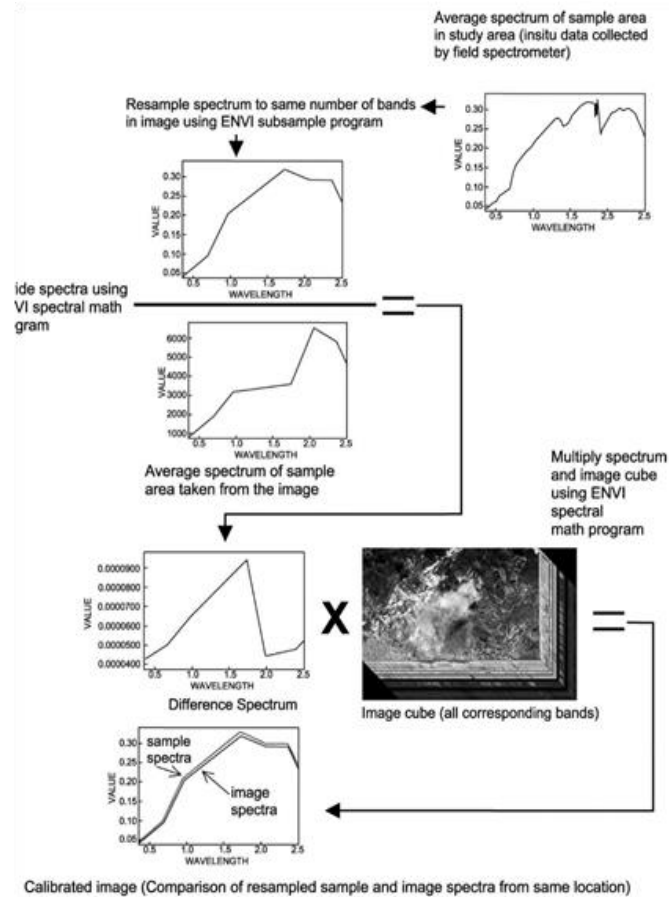

Figure 6: Steps to calibrate data ASTER by reflectance spectral measurements to map alteration zones in Pass mountain, California

OHI Index of minerals containing $\mathrm{OH}$ and KLI Kaolinite profile and ALI Alunite profile and CLI Is the calcite index as well as ninomia (2003) Index for Quartz in thermal bands ASTER-TIR Introduced, thus the quartz spectrum in bands 10 and 12 are absorbed and show a small radiative peak at 11 band:

$\mathrm{Qi}=(\mathrm{b} 11 \times \mathrm{b} 11) /(\mathrm{b} 10 \times \mathrm{b} 12)$

It is expected that the amount of Qi will be high for quartz and low for potassium feldspar [8].

\section{CONCLUSION}

The application of remote sensing in geology is very diverse and wide. One of the most important of these applications is geological mapping using remote sensing. In this study, generalities of satellite images and how to analyze and use them were expressed. Information was also provided on a range of minerals as well as various rocks. Due to the increasing development of science, it is suggested that you always expand the relationship between the two by studying new research in the field of remote sensing and earth sciences.

\section{REFERENCES}

[1] Khakmardan, S., A. Shirazi, A. Shirazy, and H. Hosseingholi, Copper Oxide Ore Leaching Ability and Cementation Behavior, Mesgaran Deposit in IRAN. Open Journal of Geology, 2018. 8(09): p. 841.

[2] Khakmardan, S., R.J. Doodran, A. Shirazy, A. Shirazi, and E. Mozaffari, Evaluation of Chromite Recovery from Shaking Table Tailings by Magnetic Separation Method. Open Journal of Geology, 2020. 10: p. 1153-1163.

[3] Doodran, R.J., S. Khakmardan, A. Shirazi, and A. Shirazy, Minimalization of Ash from Iranian Gilsonite by Froth Flotation. Journal of Minerals and Materials 
Characterization and Engineering, 2020. 9(1): p. 113.

[4] Campbell, J.B. and R.H. Wynne, Introduction to remote sensing. 2011: Guilford Press

[5] Shirazi, A., A. Shirazy, S. Saki, and A. Hezarkhani, Geostatistics Studies and Geochemical Modeling Based on Core Data, Sheytoor Iron Deposit, Iran. Journal of Geological Resource and Engineering, 2018. 6: p. 124-133.

[6] Sabins Jr, F.F., Remote sensing--principles and interpretation. 1987: WH Freeman and company.

[7] Alahgholi, S., A. Shirazy, and A. Shirazi, Geostatistical Studies and Anomalous Elements Detection, Bardaskan Area, Iran. Open Journal of Geology, 2018. 8(7): p. 697-710.

[8] Sabins, F.F., Remote sensing for mineral exploration. Ore geology reviews, 1999. 14(3-4): p. 157-183.

[9] Shirazi, A., A. Shirazy, S. Saki, and A. Hezarkhani, Introducing a software for innovative neuro-fuzzy clustering method named NFCMR. Global Journal of Computer Sciences: Theory and Research, 2018. 8(2): p. 62-69.

[10] Gupta, R.P., Remote sensing geology. 2017: Springer.

[11] Shirazi, A., A. Hezarkhani, A. Shirazy, and I. Shahrood, Exploration Geochemistry Data-Application for $\mathrm{Cu}$ Anomaly Separation Based On Classical and Modern Statistical Methods in South Khorasan, Iran. International Journal of Science and Engineering Applications, 2018. 7: p. 39-44.

[12] SHIRAZI, A. and A. HEZARKHANI, Predicting gold grade in Tarq 1: 100000 geochemical map using the behavior of gold, Arsenic and Antimony by K-means method. 2018.

[13] Shirazy, A., A. Shirazi, M.H. Ferdossi, and M. Ziaii, Geochemical and Geostatistical Studies for Estimating Gold Grade in Tarq Prospect Area by $K$ Means Clustering Method. Open Journal of Geology, 2019. 9(6): p. 306-326.

[14] Shirazy, A., M. Ziaii, A. Hezarkhani, T.V. Timkin, and V.G. Voroshilov, Geochemical behavior investigation based on k-means and artificial neural network prediction for titanium and zinc, Kivi region, Iran. Известия Томского политехнического университета, 2021. 332(3): p. 113-125.

[15] Woźniak, S.B. and D. Stramski, Modeling the optical properties of mineral particles suspended in seawater and their influence on ocean reflectance and chlorophyll estimation from remote sensing algorithms. Applied Optics, 2004. 43(17): p. 34893503.

[16] Scafutto, R.D.P.M., C.R. de Souza Filho, and W.J. de Oliveira, Hyperspectral remote sensing detection of petroleum hydrocarbons in mixtures with mineral substrates: Implications for onshore exploration and monitoring. ISPRS Journal of Photogrammetry and Remote Sensing, 2017. 128: p. 146-157.

[17] Shirazy, A., A. Shirazi, and A. Hezarkhani, Behavioral Analysis of Geochemical Elements in Mineral Exploration. 2020, Germany: LAP LAMBERT Academic Publishing.

[18] Shirazy, A., Behavior of Gold, Arsenic, and Antimony Elements: K-Means Method, Matlab, and SPSSSoftware. 2020: GRIN Verlag.

[19] Shirazi, A. and A. Shirazy, Introducing Geotourism Attractions in Toroud Village, Semnan Province,
IRAN. International Journal of Science and Engineering Applications, 2020. 9(6): p. 79-86.

[20] Jaiswal, R., S. Mukherjee, J. Krishnamurthy, and R. Saxena, Role of remote sensing and GIS techniques for generation of groundwater prospect zones towards rural development--an approach. International Journal of Remote Sensing, 2003. 24(5): p. 993-1008.

[21] Ye, Y., J. Shan, L. Bruzzone, and L. Shen, Robust registration of multimodal remote sensing images based on structural similarity. IEEE Transactions on Geoscience and Remote Sensing, 2017. 55(5): p. 2941-2958.

[22] Van Leeuwen, M. and M. Nieuwenhuis, Retrieval of forest structural parameters using LiDAR remote sensing. European Journal of Forest Research, 2010. 129(4): p. 749-770.

[23] Khan, S.D. and S. Jacobson, Remote sensing and geochemistry for detecting hydrocarbon microseepages. Geological Society of America Bulletin, 2008. 120(1-2): p. 96-105.

[24] Brekke, C. and A.H. Solberg, Oil spill detection by satellite remote sensing. Remote sensing of environment, 2005. 95(1): p. 1-13.

[25] Pour, A.B., M. Hashim, and M. Marghany, Using spectral mapping techniques on short wave infrared bands of ASTER remote sensing data for alteration mineral mapping in SE Iran. International journal of physical sciences, 2011. 6(4): p. 917-929.

[26] Kalashnikova, O.V. and R. Kahn, Ability of multiangle remote sensing observations to identify and distinguish mineral dust types: 2. Sensitivity over dark water. Journal of Geophysical Research: Atmospheres, 2006. 111(D11).

[27] Schowengerdt, R.A., Remote sensing: models and methods for image processing. 2006: Elsevier.

[28] Shirazy, A., M. ZIAII, and A. HEZARKHANI, Geochemical Behavior Investigation Based on $K$ means and Artificial Neural Network Prediction for Copper, in Kivi region, Ardabil province, IRAN. 2020.

[29] Shirazy, A., M. Ziaii, A. Hezarkhani, and T. Timkin, Geostatistical and Remote Sensing Studies to Identify High Metallogenic Potential Regions in the Kivi Area of Iran. Minerals, 2020. 10(10): p. 869.

[30] Ширази, А., 3. Мансур, А. Хезархани, Т.В. Тимкин, and В.Г. Ворошилов, ИССЛЕДОВАНИЕ ГЕОХИМИЧЕСКОГО ПОВЕДЕНИЯ ТИТАНА И ЦИНКА НА ОСНОВЕ МЕТОДА К-СРЕДНИХ И ИСКУССТВЕННЫХ НЕЙРОННЫХ СЕТЕЙ ДЛЯ ПРОГНОЗИРОВАНИЯ НОВЫХ ПЛОЩАДЕЙ, РЕГИОН КИВИ, ИРАН. Izvestiya Tomskogo Politekhnicheskogo Universiteta Inziniring Georesursov, 2021. 332(3): p. 113-125.

[31] Ninomiya, Y. and B. Fu, Thermal infrared multispectral remote sensing of lithology and mineralogy based on spectral properties of materials. Ore Geology Reviews, 2019. 108: p. 54-72.

[32] Salisbury, J.W. and L.S. Walter, Thermal infrared (2.5$13.5 \mu \mathrm{m})$ spectroscopic remote sensing of igneous rock types on particulate planetary surfaces. Journal of Geophysical Research: Solid Earth, 1989. 94(B7): p. 9192-9202.

[33] Planke, S., H. Svensen, R. Myklebust, S. Bannister, B. Manton, and L. Lorenz, Geophysics and remote sensing, in Physical geology of shallow magmatic systems. 2015, Springer. p. 131-146. 
[34] Khan, S.D., K. Mahmood, and J.F. Casey, Mapping of Muslim Bagh ophiolite complex (Pakistan) using new remote sensing, and field data. Journal of Asian Earth Sciences, 2007. 30(2): p. 333-343.

[35] Legg, C., Remote sensing and geographical information systems: geological mapping, mineral exploration and mining. 1994.

[36] Rencz, A.N. and R.A. Ryerson, Manual of remote sensing, remote sensing for the earth sciences. Vol. 3. 1999: John Wiley \& Sons.

[37] Van der Meer, F.D., H.M. Van der Werff, F.J. Van Ruitenbeek, C.A. Hecker, W.H. Bakker, M.F. Noomen, M. Van Der Meijde, E.J.M. Carranza, J.B. De Smeth, and T. Woldai, Multi-and hyperspectral geologic remote sensing: A review. International Journal of Applied Earth Observation and Geoinformation, 2012. 14(1): p. 112-128.

[38] Dubucq, D., L. Turon, B. Blanco, and H. Bideaud, Earth observation remote sensing for oil and gas: A new era. The Leading Edge, 2021. 40(1): p. 26-34.

[39] Serkan Öztan, N. and M. Lütfi Süzen, Mapping evaporate minerals by ASTER. International Journal of Remote Sensing, 2011. 32(6): p. 1651-1673.

[40] Shirazy, A., A. Shirazi, S. Heidarlaki, and M. Ziaii, Exploratory Remote Sensing Studies to Determine the Mineralization Zones around the Zarshuran Gold Mine. International Journal of Science and Engineering Applications, 2018. 7(9): p. 274-279.

[41] Manuel, R., M.D.G. Brito, M. Chichorro, and C. Rosa, Remote sensing for mineral exploration in central Portugal. Minerals, 2017. 7(10): p. 184.

[42] Goetz, A.F., B.N. Rock, and L.C. Rowan, Remote sensing for exploration; an overview. Economic Geology, 1983. 78(4): p. 573-590.

[43] Calvin, W.M., E.F. Littlefield, and C. Kratt, Remote sensing of geothermal-related minerals for resource exploration in Nevada. Geothermics, 2015. 53: p. 517-526.

[44] Shirazi, A., A. Hezarkhani, A. Shirazy, and I. Shahrood, Remote sensing studies for mapping of iron oxide regions, South of Kerman, Iran. International Journal of Science and Engineering Applications, 2018. 7(4): p. 45-51.

[45] Safari, M., A. Maghsoudi, and A.B. Pour, Application of Landsat-8 and ASTER satellite remote sensing data for porphyry copper exploration: a case study from Shahr-e-Babak, Kerman, south of Iran. Geocarto international, 2018. 33(11): p. 1186-1201.

[46] Safari, M., A.B. Pour, A. Maghsoudi, and M. Hashim, TARGETING HYDROTHERMAL ALTERATIONS UTILIZING LANDSAT-8 ANDASTER DATA IN SHAHR-E-BABAK, IRAN. International Archives of the Photogrammetry, Remote Sensing \& Spatial Information Sciences, 2017. 42.

[47] Bersi, M., H. Saibi, and M.C. Chabou, Aerogravity and remote sensing observations of an iron deposit in Gara Djebilet, southwestern Algeria. Journal of African Earth Sciences, 2016. 116: p. 134-150.
[48] Ahmadi, H. and H. Uygucgil, Targeting iron prospective within the Kabul Block (SE Afghanistan) via hydrothermal alteration mapping using remote sensing techniques. Arabian Journal of Geosciences, 2021. 14(3): p. 1-22.

[49] Agharezaei, M. and A. Hezarkhani, Delineation of geochemical anomalies based on $\mathrm{Cu}$ by the boxplot as an exploratory data analysis (EDA) method and concentration-volume $(\mathrm{CV})$ fractal modeling in Mesgaran mining area, Eastern Iran. Open Journal of Geology, 2016. 6(10): p. 1269-1278.

[50] Ahmadi, H. and K. Kalkan, Mapping of Ophiolitic Complex in Logar and Surrounding Areas (SE Afghanistan) With ASTER Data. Journal of the Indian Society of Remote Sensing, 2021: p. 1-14.

[51] Ahmadi, H. and A.B. Rahmani, STUDY ON THE MINERAL ANOMALIES OF MUQUR-CHAMAN FAULT AND ITS COMPARISON WITH HARIRUD (HERAT) FAULT (AFGHANISTAN) USING GEOPHYSICAL AND REMOTE SENSING (ASTER-HyMap) DATA. Геология и охрана недр, 2018(1): p. 28-38.

[52] Shirazi, A., A. Shirazy, and J. Karami, Remote Sensing to Identify Copper Alterations and Promising Regions, Sarbishe, South Khorasan, Iran. International Journal of Geology and Earth Sciences, 2018. 4(2): p. 36-52.

[53] Mora, J., C. Armas-Herrera, J. Guerra, A. RodríguezRodríguez, and C. Arbelo, Factors affecting vegetation and soil recovery in the Mediterranean woodland of the Canary Islands (Spain). Journal of arid environments, 2012. 87: p. 58-66. 